\title{
STUDENT FACTORS INFLUENCING CHEATING IN UNDERGRADUATE EXAMINATIONS IN UNIVERSITIES IN KENYA
}

\author{
David Kiptanui Ruto, Lydia Cheruto Kipkoech, Daniel Kimutai Rambaei \\ Moi University, Eldoret, Kenya \\ E-mail: davidkrutocheribo@gmail.com, cherulk@yaho.com,dkrambaei@yahoo.com
}

\begin{abstract}
University examinations form the final and most integral part of assessing any student's acheivement, knowledge, skills, and attitudes. However, there has been a public outcry over the rise of irreqularities in primary, secondary, and even university examinations. The purpose of this research was to investigete the student factors which influenc cheating in the undergraduate university examinations. The study design was a descriptive suvey. A sample of fifty students and ten lecturers was selected using random sampling technique. Data were collected using a questionnaire, structured interview, and document analysis. A pilot study was carried out in the school of education in one of the public universities. Data were analyzed using descriptive statistics generated with the help of Statistical Package for Social Sciences (SPSS) programme, and were presented by use of frequency tables. The results revealed that majority of the students do not attend lectures, and factors such as lack of preparedness for examinations, peer influence, pressure from work place, and students' lack of confidence were some of the factors contributing to cheating in examinations. Effective procedures and policies for management of examinations are also recommended to be put in place, strictly observed, and effective deterrrent measures be implemented. It was recommended that employers give off-days or study leave to staff who enroll for various courses.

Key words: cheating, dishonesty, exam irregularity, integrity, management of examinations, university examinations.
\end{abstract}

\section{Introduction}

University examinations form a very important part in assessing the knowledge, skills, and attitudes of students who have reached the highest academic institutions in any country.

The management of national examinations for primary and secondary schools in Kenya is largely the responsibility of the Kenya National Examinations Council, which lays out the rules and regulations governing the conduct of examinations.

Each university in Kenya has its rules and regulations governing the management of examinations. For example, in Moi University, there are rules and regulations that govern the management and conduct of undergraduate and postgraduate examinations (Moi University, 2009). In the rules and regulations are stipulated categories of examination irregularities, procedures for dealing with examination irregularities, and the penalties for various categories of examination irregularities such as: one or a combination of actions like giving a warning, cancellation of examination results, suspensions for a given period of time, or expulsion from the university, depending on the nature of the irregularity committed. The rules and regulations highlight areas that constitute an examination irregularity, and hence, warn students against committing the stated offences.

Despite of the fact that examinations are important in primary school, secondary school, 
PROBLEMS

OF MANAGEMENT

IN THE $21^{\text {st }}$ CENTURY

Volume 2, 2011

174

and university assessments of achievement, there have been increasing cases of irregularities reported before, during, and after administration of the examinations. This has raised a public outcry especially as a result of cases of reported examination leakages, sale of examination papers prior to examination periods, and cancelled examination results. Cheating in examinations occurs in every country in the world (Harold \& Max, 2001). In a European context, according to a study by Newstead, Franklyn-Stolles, and Armstead (1996), there were high rates of cheating with only $12 \%$ of the participants indicating they had not cheated, and that goal-motivated cheating was reported among college students in the United Kingdom. This was supported in the literature that examination malpractice was a global issue (Ikupa, 1997).

\section{Problem of Research}

Curry, the government and the parents are spending a lot in financing education in Kenya. At the same time, the education sector is responsible for producing the manpower that will be expected to propel the government towards realization of vision 2030. The government and parents are concerned about the kind of graduates produced in the learning institutions especially after several cases of examination cheating were reported. Cheating in examinations should be discouraged since it has a negative influence on the future of society. According to Alutu and Alutu (2003), examination malpractice is undesirable behavior and should be sternly discouraged. The negative impact of examination cheating on society is supported by Becker, Connoly, Lentz, and Morrison (2006) who established that dishonesty in the work place is influenced by dishonesty while attending university. This then suggests that those students who cheat were likely to cheat after studies and while in their work places. Since a number of factors may influence the decision to cheat, Kisamore, Stone, and Jawahar (2007); and McCabe, Trevino, and Butterfield (2001) found that personal factors and situational factors affect intentions to cheat. The purpose of this research was to investigate student factors which influenced cheating in undergraduate university examinations.

\section{Research Focus}

This study focuses on factors that are attributed to students that influence them to cheat in examinations. This concern is as a result of a number of cases of reported examination irregularities and general concern from the government, parents and members of the public.

Past studies and literature have pointed out various concerns about academic integrity. Whitley and Keith-Spiegel (2002, pp. 4-6), based on a number of studies, pointed out the following as reasons that educators should be concerned with academic integrity:

Equity: Students who cheat may be getting higher grades than they deserve. That, in addition, when student grades are assigned on the basis of average score in the class, students who do not cheat may get less than they deserve whenever cheaters raise class average.

Character development: Students who see that no action is taken against those who cheat take academic dishonesty as acceptable, thus, influencing their character.

The mission to transfer knowledge: Students who cheat in exams in higher education may not acquire the knowledge to which their degrees are supposed to attest as it diminishes the intellectual and moral capital required by society for its development.

Student morale: cheating discourages, kills the morale, and frustrates students who do not cheat if they see those who cheat going unpunished. Some students may be discouraged from working hard and may also resort to cheating.

Faculty morale: The staff members become stressed dealing with cases of cheating, and feel personally violated and mistreated by the students who cheat. 
Students' future behaviour: Students who cheat can easily cheat in their professional careers, hence, become a disservice to the academic community and the society at large.

Reputation of the institution: Massive cheating that attracts media or widespread coverage may bring the name of the institution into disrepute, hence tarnishing its future reputation.

Public confidence in higher education: if academic dishonesty is not addressed, may lead to loss of confidence from the members of the public, and employers lose confidence on the quality of the graduates, and hence, their employees.

\section{Causes of Cheating}

Many researchers have pointed out a number of factors that influence students to cheat in examinations. Davis, Drinan, and Gallant (2009) reported that the situations that students find themselves in are to blame for cheating. These situations include stress and pressures for good grades. They further reported that students also willingly enter into collusion with other students to cheat, while large crowded classrooms also fostered cheating.

McCabe and Trevino (1997) examined individual-level variables and found that, students with lower GPAs report more cheating than those with high GPAs. They also reported that students who engaged in inter-college athletics and other extra-curricular activities self-reported more cheating. This reflects time demands on the part of students, hence, attempt to take short cuts to remain competitive in their performance.

In another qualitative study, McCabe, Trevino, and Butterfield (1999) identified factors that influence cheating such as pressure to get high grades, parental pressures, a desire to excel, pressure to get a job, laziness, lack of responsibility, lack of good character, poor self-image, lack of pride in the job well done, and a lack of personal integrity.

\section{Methodology of Research}

\section{General Background of Research}

In this study, the study design used was a descriptive survey. According to Cohen, Manion, and Morrison (2000: 169), surveys are used to gather data at a particular point in time, with the intension of describing the nature of existing conditions, or identifying standards against which existing conditions can be compared' or determining the relationship between specific events.

\section{Sample of Research}

A sample of 50 students and 10 lecturers was selected using simple random sampling technique. The participants were chosen from those in the regular and school-based programmes, while the lecturers were those who teach all programmes.

\section{Instrument and Procedures}

Data were collected by the use of a questionnaire and a document analysis. A pilot study was carried out in the school of education in one of the public Universities in Kenya. The questionnaire $\mathrm{w}$ a preferred tool for this study because it enabled the researcher to get views from a larger number of participants within a short time. The questionnaire contained both openended and closed-ended questions. A structured face-to-face interview was carried out with some of the lecturers. The interview items were unstructured in order to encourage participants 
PROBLEMS

OF MANAGEMENT

IN THE $21^{\text {st }}$ CENTURY

volume 2, 2011

to respond open-endedly and to answer in their own terms (Scott \& Morrison, 2006).

The third method used in data collection was the document analysis. Robson (2002) defines document analysis as a social research method and is an important research tool in its own right. It involves reading lots of written materials and relating to some aspect of the social world. These include public records, books, media, manuals, guides etc. Robson (2002) points out the advantages of document analysis. And advantage is that documents are unobtrusive and can be used without imposing on participants; they can be checked and rechecked for reliability. The documents analyzed included reports on examination irregularities from schools, and reports of action taken on students involved.

\section{Ethical Considerations}

According to Kombo and Tromp (2006), the researcher must maintain privacy and confidentiality of the respondent at all times. In doing this research the researcher respected the respondents' privacy. The participants were not expected to write their names on the questionnaires. The participants were assured that the information given would be treated with a lot of confidentiality and for the purpose intended only. The participants were also given the freedom to withdraw from the study at any point or time. The name of the institution was also not disclosed due to the sensitivity of the research problem.

\section{Data Analysis}

Data were analyzed using descriptive statistics generated with the help of the Statistical Package for Social Sciences (SPSS) programme to generate frequencies, percentages, means, and standard deviations. Data were presented in form of tables.

\section{Results of Research}

The results of the research obtained from questionnaires were as explained in this section.

Table 1. Students involved in examination irregularities during the last one year.

\begin{tabular}{|c|c|c|c|c|}
\hline \multicolumn{2}{|c|}{ Male } & \multicolumn{2}{c|}{ Female } & Total \\
\hline Frequency & Percentage & Frequency & Percentage & \\
\hline 47 & 63.5 & 27 & 36.5 & 74 \\
\hline
\end{tabular}

In Table 1 above based on the results from the documents found at the Academic Office, it was revealed that in the last one year alone, 74 cases of examination irregularities were recorded. It was further revealed that majority of those involved in the irregularities were male (63.5\%), while females involved were lower (36.5\%).

It was also revealed that among the factors cited by students for cheating in examinations included poor preparation for examinations, confusion that made students enter examination rooms with written papers, pressure from parents, place of work pressures, delayed fees payments, late clearance to do the examinations, and reported parental illnesses. 
Table 2. Ranking of Student factors that influence cheating based on the mean of the responses.

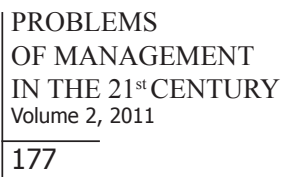

\begin{tabular}{|l|c|c|c|}
\hline Channel & Mean & Rank & Standard Deviation \\
\hline Inadequate preparation & 2.9900 & 1 & 1.1561 \\
\hline Influence by colleagues & 2.9369 & 2 & 1.0767 \\
\hline Poor attendance of lectures & 2.5814 & 3 & 1.0851 \\
\hline Lack of confidence & 2.3522 & 4 & 1.1086 \\
\hline Pressure from work place & 1.9668 & 5 & 0.9232 \\
\hline
\end{tabular}

Table 2 above reveals that majority of the students ranked as first inadequate preparation for examination as the main factor that contributed to cheating in examinations, with a mean of 2.99 on a $1-5$ scale. This was followed by reasons such as influence by colleagues, poor attendance of lectures, lack of confidence from the student, and pressure from work place in that order respectively.

Table 3. Suggestions to minimize cases of cheating in examinations.

\begin{tabular}{|l|c|c|}
\hline Response & Frequency & Percentage \\
\hline Provide large examination rooms & 31 & 62 \\
\hline Sign attendance lists in all lecture to avoid absenteeism & 11 & 22 \\
\hline Invigilators should be in exam room all the time & 11 & 22 \\
\hline Search for unauthorized material before beginning of exams & 7 & 14 \\
\hline Sitting arrangement should be far apart & 6 & 12 \\
\hline Severe punishment to those caught cheating & 6 & 12 \\
\hline Expel those who cheat & 5 & 10 \\
\hline Avoid over drinking & 4 & 8 \\
\hline
\end{tabular}

NB: the frequency is more than 50 due to more than one response from some participants

As in Table 3 above, majority of the students indicated that, to minimize cheating in examinations, there was need to provide large examination rooms $(62 \%)$. This was flowed by the suggestion that students should sign attendance registers whenever they attended lectures $(22 \%)$ and that invigilators should be in the examination rooms all the time (22\%). In the fourth place was searching students before start of examination (14\%), followed by placing students far apart in the examination room (12\%), severe punishment to those caught cheating $(12 \%)$, expelling those who cheat (10\%), and students avoiding overdrinking $(8 \%)$.

\section{Discussion}

The results of the study revealed that majority of the students involved in examination irregularities were mae at $63.5 \%$. this could be attributed to the high population of male students in public universities. This agrees with the Ministry of Education, Science \& Technology's (2004) report that female students in public universities constitute only 33\% mainly in arts based courses. The affirmative action where female students are admitted one point lower than that of males may have slightly raised the female ratio.

The results also showed that most students ranked in first position the lack of preparation for examinations as a factor that contributed more to cheating in examinations. This could be supprted by the fact that some students do not attend most of the lectures, hence, feel that they are not adequately prepared to do the examination. They therefore resort to getting into the 
PROBLEMS

OF MANAGEMENT

IN THE $21^{\text {st }}$ CENTURY

Volume 2, 2011

178

examinations if they know from past experience that they can walk into the examination room with unauthorised material and use the in examinations without being caught due to weak invigilation. This corroborates with a study by Davis and Ludvigson (1995) who established in a study that those who cheat during their university-level studies are the ones who have also cheated in earlier studies or examinations.

Peer influence was anothe factor that students and lectures cited as contibuting to cheating. This could be a result of lack of strict invigilation which allows those who cheat not to be noticed. This make other students feel that one can cheat and still go unpunished. This corroborates with previous research studies that revealed the existence of many university lectures who hesitate to take action against cheating behavior of students because of stress and discomfort that follows (Murray, 1996).

It was also revealed that poor attendance of lectures and lack of confidence on the part of the students was a contributor to cheating in examinations. This could be attributed to some students who misuse their time in the university or do not take their studies seriously. Other researches have confirmed this and revealed that, low self control among students at the University of Oklahoma was also another factor in academic dishonesty(Cochran, Wood, Sellers, Wilkerson, \& Chamlin, 1998), and that cheating at an Australian university occured due to low levels of commitment by students (Caruana, Ramaseshhau, \& Ewing, 2000).

The results reveal that pressure from work place as well as pressure from parents made some students resort to cheating. These could be attributed to situations were some parents demand better grades from their childred. These findings corroborate with the findings of Davis, Grover, Becker, and McGregor (1992) who reported that pressures for good grades, stress, and ineffective deterrents were some of the determinants of cheating, while Wolfolk (2004) found that cheating can occur if students are in a situation that demands high achievement while the opportunity for it is less. On the other hand, some employers do not want to release their staff for studies, hence, expect them to be in their work stations all the time. This may create work pressure on the part of the affected staff. According to Lipson and MacGavern (1993), student workload was an important facting explaining cheating in examinations.

In oder to minimize cases of cheating in examination, the lecturers and students recommended provision of large examination rooms, students to strictly sign lecture attendance lists, thorough searching before entering examination roomes, and giving severe punishments to those found cheation. This corroborates with the fact that most universities in Kenya lack adequate teaching facilities such as lecture halls and other facilities. This results in congestion and the situantion worsens during examination periods where more space is required. This result relates to Earthman's (2004) view that students acheivement was linked to the quality of facilities. On the severity of deterrents, it is evident that those found with serious examination irregularities get away unpunished or are given lighter punishments. This view is in agreement with past research where it was evident that punishments were mild and frequently not supported by the university administration (Bailey, 2001).

\section{Conclusions}

The literature reveals that academic dishonesty is a global issue (Ikupa, 1998) and needs to be addressed in order to improve the credibility of examination grades and certificates that students get at the end of each educational level. It was concluded from the study that, student factors that contributed to cheating in examinations include; poor attendance of lectures, lack of preparedness for the examinations, peer influence, pressure from work place, and students' lack of confidence. It is therefore recommended that employers give off-days or study leave to their staff that enroll for various degree courses. Further, large examination rooms should be 
set in order to enable students sit far apart during examinations in order to minimize cheating incidences.

It is also recommended in this study that effective measures should be taken by those in charge of administration of examinations in public universities to discourage students from cheating in examinations. All examination procedures, right from setting to sitting of the examinations, should be observed. This is supported by the fact that procedures for examinations can prevent cheating (Kerklvit \& Sigmund, 1999, in Howell, 2006). Students should also be given frequent reminders that cheating in examination may lead to severe consequences, as noted also by Kilber (1993), that there was need to talk with students about academic dishonesty and ethics.

Situations that students find themselves in should be detected so that proper guidance and counseling could be provided to avoid stressful environments during examinations. University administrators through the respective deans of students should be able identify and handle student problems that may lead to stressful situations.

It is further recommended that heads of schools in both primary and secondary schools should ensure that proper procedures that discourage cheating are established or strictly followed to inculcate ethical behavior amongst their students. This will limit students from transiting to university with cheating behaviors. This agrees with Whitley's (1998) finding that those who cheated in high school were likely to cheat in college.

\section{References}

Alutu, O., \& Alutu, A. (2003). Examination Malpractices Among Undergraduates in a Nigerian University: Implications for Academic Advising. Guidance and Counselling, 18: 149-152.

Becker, D., Connoly, J., Lentz, P., \& Morrison, J. (2006). Using Business Fraud Triangle to Predict Academic Dishonesty Among Business Students. Academy of Educational Leadership Journal, 10, (1), $37-52$.

Caruana, A., Ramaseshau, B., \& Ewing, M. (2000). The Effect of Anomie on Academic Dishonesty Among University Students. The International Journal of Educational Management, 14, 23, 23-30.

Cochran, J., Wood, P., Sellers, C., Wilkerson, W., \& Chamlin, M. (1998). Academic Dishonesty and Low Self Control: An Empirical Test of a General Theory of Crime. Deviant Behavior: An Interdisciplinary Journal, 19, 227-255.

Cohen, L., Manion, L., \& Morrison, K. (2000). Research Methods in Education. London: Routledge Falmer.

Davis, S. F., Drinan, P. F., \& Gallant, T. P. (2009). Cheating in School. Wiley-Blackwell Publishing.

Davies, S., Grover, C., Becker, A., \& McGregor, L. (1992). Academic Dishonesty: Prevalence, Determinants, Techniques, and Punishments. Teaching of Psychology, 19, 1, s. 16-20.

Davis, S., \& Ludvigson, H. (1995). Additional Data on Academic Dishonesty and Proposal for Remediation. Teaching Psychology, 22, 2, p. 119-121.

Earthman, G. I. (2004). Prioritization of 31 Criteria for School Building Adequacy. Americal Civil Liberties Union Foundation of Maryland, Baltimore, MD.

Harold, J., \& Max, A. (2001). Fraud and Education. The Norm in the Apple. Lanham, MD: Ronman and Litlefied. 
PROBLEMS

OF MANAGEMENT

IN THE $21^{\text {st }}$ CENTURY

Volume 2, 2011

180

Howell, C. (2006). Contextualizing Cheating Research: A Modest Proposal: AERA Proposal - Moral Development SIG. 1.

Ikupa, J. C. (1997). Causes and Cure of Examination Malpractices. The Business Administrator, 1 (1): 38-39.

Kibler, W. (1993). Academic Dishonesty: A Student Development Dilema. NASPA Journal, 30, 252267.

Kisamore, J., Stone, T., \& Jahawar, I. (2007). Academic Integrity: The Relationship Between Individual and Situational Factors on Misconduct Contemplations. Journal of Business Ethics, 75, 381-394.

Kombo, K. D., \& Tromp, A. L. D. (2006). Proposal Wand Thesis Writing: An Introduction. Nairobi: Paulines Publishing Africa.

Lipson, A., \& MacGavern, N. (1993). Undergraduate Academic Dishonesty at MIT. Results From a Study of Attitudes and Behavior of Undergraduate, Faculty, and Graduate Teaching Assistants.

McCabe, D. L., Trevino, L. K. (1997). Individual and Contextual Influences on Academic Dishonesty. Research in Higher Education, 38, 379-396.

McCabe, D. L., Trevino, L. K., \& Butterfield, K. D. (2001). Cheating in Academic Institutions: A. Decade of Research, Ethics and Behavior, 11, 219-232.

McCabe, D. L., Trevino, L. K., \& Butterfield, K. D. (1999). Academic Integrity in Honor Code and NonHonor Code Environment: A Qualitative Investigation. Journal of Higher Education, 70, 211-234.

Ministry of Education, Science \& Technology (2004). Development of Education in Kenya. Nairobi: MOE.

Moi University (2009). Common Rules and Regulations for Undergraduate Examinations (Revised).

Murray, B. (1996). Are Professors Turning a Blind Eye on Cheating? Schools Facing a Plaque of cheating. Beware the "A" Student: Overachievers can be Cheaters. The APA MONITOR, 27, 1, p. 1, 42.

Newstead, S. E., Franklyn-Stolles, A., \& Armstead, P. (1996). Individual Differences in Student Cheating. Journal of Educational Psychology, 88, 229-241.

Robson, C. (2002). Real World Research, $2^{\text {nd }}$ Ed. Oxford: Blackwell.

Scott, David, \& Morrison, Marlene (2006). Key Ideas in Educational Research. London/New York: Continuum International Publishing Group.

Whitley, B. E., \& Keith-Spiegel, P. (2002). Academic Dishonesty. An Educator's Guide. London: Lawrence Erlbaum Associates Inc. Publishers.

Wolfolk, A. (2004). Educational Psychology. NJ: Prentice-Hall Inc.

Advised by Vincentas Lamanauskas, University of Siauliai, Lithuania

Received: September 15, 2011

Accepted: October 30, 2011 
David Kiptanui RUTO, Lydia Cheruto KIPKOECH, Daniel Kimutai RAMBAEI. Student Factors Influencing Cheating in Undergraduate Examinations in Universities in Kenya

PROBLEMS

OF MANAGEMENT

IN THE $21^{\text {st }}$ CENTURY

Volume 2, 2011

181

\begin{tabular}{|ll|}
\hline David Kiptanui Ruto & $\begin{array}{l}\text { Doctor of Philosophy in Educational Administration and Planning, Adminis- } \\
\text { trative Officer, Moi University P.O. Box 3900-30100 Eldoret, Kenya. } \\
\text { E-mail: davidkrutocheribo@gmail.com }\end{array}$ \\
\hline Lydia Cheruto Kipkoech & $\begin{array}{l}\text { Doctor of Philosophy in Educational Administration, Moi University P.O. } \\
\text { Box 3900-30100 Eldoret, Kenya, Administrative Officer, Master of Arts in } \\
\text { Economics. } \\
\text { E-mail: cherulk@yahoo.com }\end{array}$ \\
\hline Daniel Kimutai Rambaei & $\begin{array}{l}\text { Master of Arts in Economics, Moi University P.O. Box 3900-30100 Eldoret, } \\
\text { Kenya, Administrative Officer. } \\
\text { E-mail: dkrambaei@yahoo.com }\end{array}$ \\
\hline
\end{tabular}

